Mr Vlado Radic, kapetan I klase, dipl. inž.

\section{Određivanje količine eksploziva pri obradi metala eksplozijom}

\section{Uvod}

Ovaj članak predstavlja samostalan stručni rad i kontinualan logičan nastavak radova od istog autora, do sada objavljenih u ovom časopisu.

Određivanje količine eksploziva pri izvlačenju eksplozijom u vodi pomocu brizantnih eksploziva predstavlja sustinski problem. Jer, potrebno je odrediti minimalnu količinu eksploziva koja će biti dovoljna za izvlačenje. Svako nepotrebno povećanje mase eksploziva dovodi do prevremenog razaranja alata i bazena u kojem se vrši eksplozija.

Zbog složenosti samog procesa podvodne eksplozije, praktično je nemoguce abuhvatiti sve faktore koji se pri tome javljaju i utiču na sam proces. Moguće je steći približnu predstavu fizikalnosti ove pojave, ali se ona, na žalost, ne može izraziti jednostavnim formulama.

Na pripremak, pored pritiska udarnog talasa i širenja gasnog mehura, deluju difrakcioni talasi koji se javljaju kao rezultat neravnomernog pomeranja delova pripremka u centru i njegovim krajevima, kao i talasi odbijeni od zidova bazena, njegovog dna i slobodne površine vode.

Novija teorija podvodne eksplozije omogućava da se na relativno jednostavan način odredi energija direktnog talasa koja se predaje pripremku. Mno- go složenije je određivanje energije sledećeg protoka tečnosti i difrakcionog izjednačavanja pritiska, pri čemu je moguća i veća greška. Sasvim je nepoznat deo energije dobijen bočnim strujanjem tečnosti koja popunjava vakuum iznad pripremka. Takođe, moguce je odrediti, istina veoma teško, energiju talasa odbijenih od zidova, dna bazena i slobodne površine tečnosti.

Teorija o uticaju spoljnih opterećenja na pripremak nije dovoljno razrađena, pa se, pri proračunu deformacije membrane, prema teoriji Kirkvuda-Bete, prave velike greške.

Navagin je pokušao da iskoristi teorijske osnove hidrodinamicke eksplozije uz pomoć teorije sličnosti, pri obradi lima izvlačenjem. Formula koju je predložio daje dovoljno dobre rezultate u poređenju sa eksperimentima samo za pripremke prečnika $30-150 \mathrm{~mm}$. $\mathrm{Za}$ prečnike veće od $150 \mathrm{~mm}$ dolazi do velikog odstupanja između proračunskih i eksperimentalnih vrednosti. Pored toga, Kirkvud i Navagin, u svojim istraživanjima, ograničili su se na deformacije okrugle membrane. To je, naravno, daleko od prakticnih zahteva izrade.

Pri izvlačenju lima eksplozijom, pritisci udarnog talasa su u dijapazonu od $1500-2000 \mathrm{MPa}$ [9]. Pri tim pritiscima odnos brzine protoka tečnosti (U) i brzine zvuka $\left(\mathrm{C}_{0}\right)$ u toj sredini $-\mathrm{M}=$ $=\mathrm{U} / \mathrm{C}_{0}$, uvek je manji od jedinice. Uzi- 
majući u obzir tu činjenicu, proračuni se mogu izvesti na osnovu zakona akustike. Na taj način moguće je izbeći složene hidrodinamičke proračune udarnih talasa [10]. Greška koja se cini pri takvoj aproksimaciji je zanemarljiva. Druga pretpostavka - ravno kretanje pripremka $u$ početnom trenutku i zanemarljivo mala deformacija u tom vremenu - može prouzrokovati veću grešku.

Danas se raspolaže sa dovoljno eksperimentalnih podataka, što omogućava da se pretpostavi kako se u pocetnom trenutku izvlačenja deformiše samo venac, a dno pripremka ostaje ravno (slika). U tom trenutku pripremak se može posmatrati kao ravna membrana $\chi_{i j i}$ su otpori kretanju sile inercije $i$ sile vezane za otpor defomisanog venca, pri čemu se ove druge, bez veće greške, mogu zanemariti.
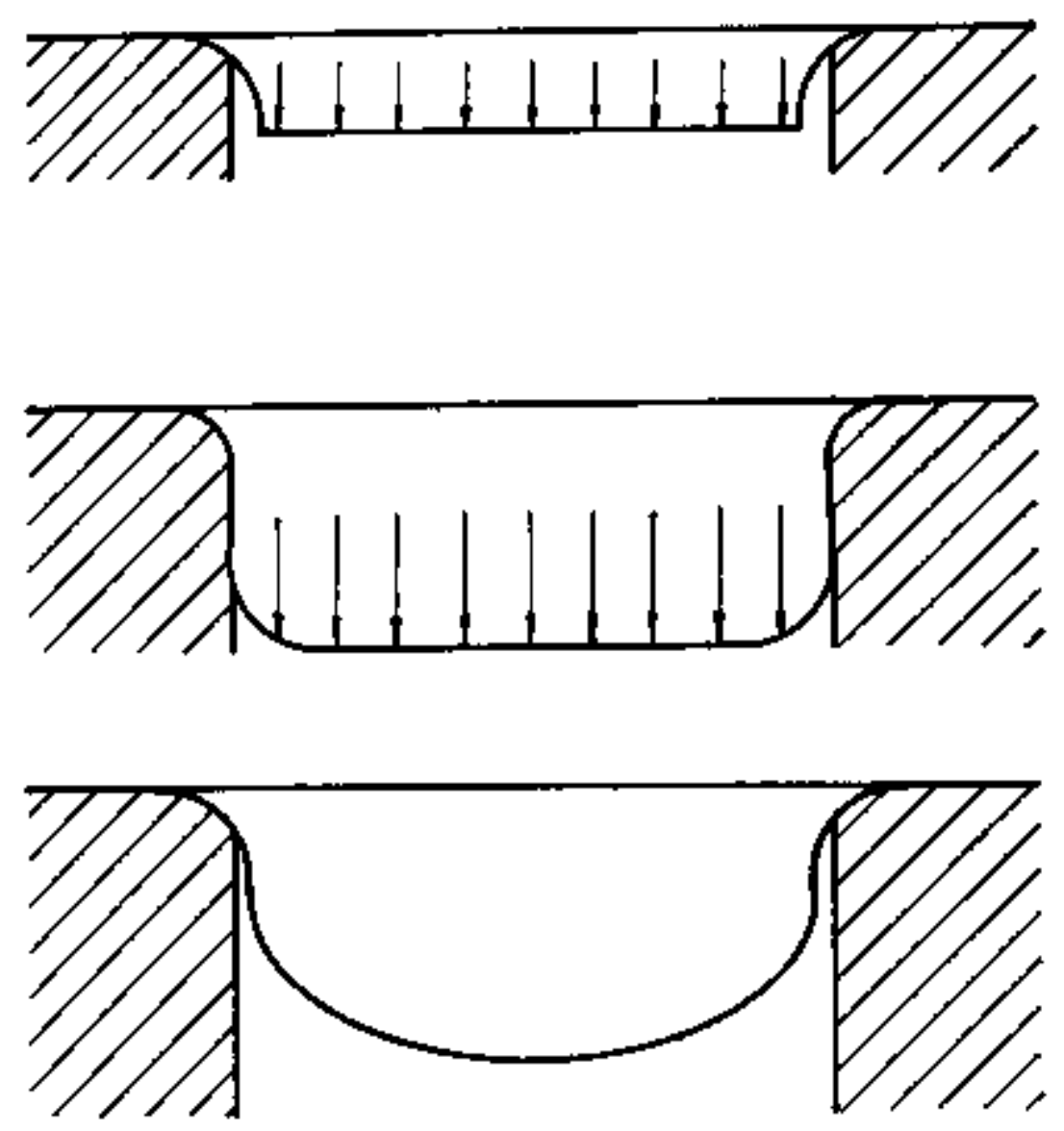

Sl. 1 Deformaciono stanje pri izvlačenju eksplozijom

Nakon toga, pošto se dejstvo impulsa stvorenog eksplozijom prekida. plastična deformacija venca i njegovo kretanje se zaustavljaju, a dno pripremka deformiše pod dejstvom kineticke energije apsorbovane u njemu. Prihva- tanje ovakve sheme deformisanja, bez veće greške, podrazumeva da se u početnom trenutku dno pripremka deformiše kao membrana, a da su sile vezane za plastično deformisanje venca male.

Treće uprošćenje je zanemarivanje uticaja difrakcije i talasa odbijenih od zidova, dna bazena i slobodne površine tečnosti. Veličina te greške zavisi od konkretnih uslova pri kojima se odvija proces. Ako se koriste bazeni malih gabarita i malog nivoa vode iznad eksploziva, greška može biti znatna.

\section{Gubici energije pri odbijanju udarnog talasa od evrste pregrade}

Pri dejstvu udarnog talasa na nepokretnu čvrstu pregradu energija talasa delimično se odbija, a delimično predaje pregradi. Ako sa P, U i E oznacimo pritisak, brzinu i energiju udarnog talasa, a indeksima $» 1 \ll, n 2 \ll$ i $» 3 \ll$ direktan, odbijeni i prelomljeni talas, u slučaju da je akustična otpornost pregrade $(\rho \mathrm{C})$ veća od akustičnog otpora tečnosti $\left(\rho_{n} C_{n}\right)$, dobija se:

$$
\begin{aligned}
& \mathrm{P}_{1}+\mathrm{P}_{2}=\mathrm{P}_{3} \\
& \mathrm{U}_{1}-\mathrm{U}_{2}=\mathrm{U}_{3}
\end{aligned}
$$

Pored toga, pritisak (P) i brzina (U) povezani su odnosom

$$
\mathrm{P}=\rho \mathrm{CU}
$$

Iz navedenih jednačina moguće je dobiti sledeće odnose

$$
\begin{aligned}
& \frac{\mathrm{P}_{2} \mathrm{U}_{2}}{\mathrm{P}_{1} \mathrm{U}_{1}}=\frac{\rho \mathrm{C}-\rho_{0} \mathrm{C}_{0}}{\rho \mathrm{C}+\rho_{0} \mathrm{C}_{0}}=\xi \\
& \frac{\mathrm{P}_{3}}{\mathrm{P}_{1}}(1+\xi)=-\frac{2 \rho \mathrm{C}}{\rho \mathrm{C}+\rho_{0} \mathrm{C}_{6}}=\eta
\end{aligned}
$$

U procesu delovanja udarnog talasa na pregradu, pritisak (P) i brzina strujanja tečnosti (U) menjaju se u vremenu pod određenom zakonu [10]. Ako se uzmu srednje vrednosti za pritisak $i$ 
brzinu u vreme delovanja udarnog talasa (t), onda se ukupan rad (A) srednjeg pritiska za pomeranje (U-t) može napisati u obliku:

$$
\begin{aligned}
& A_{1}=P_{1} U_{1} t \\
& A_{2}=P_{2} U_{2} t \\
& A_{3}=P_{3} U_{3} t
\end{aligned}
$$

Ako se taj rad svede na jedinicu površine i uzme da je približno jednak energiji udarnog talasa, dobija se:

$$
\begin{aligned}
& \mathrm{E}_{1}=\mathrm{P}_{1} \mathrm{U}_{1} \mathrm{t} \\
& \mathrm{E}_{2}=\mathrm{P}_{2} \mathrm{U}_{2} \mathrm{t} \\
& \mathrm{E}_{3}=\mathrm{P}_{3} \mathrm{U}_{3} \mathrm{t}
\end{aligned}
$$

Iz odnosa energija odbijenog $\left(\mathrm{E}_{2}\right)$ i direktnog talasa $\left(\mathrm{E}_{1}\right)$, za isti interval vremena (t), dobija se koeficijent odbijanja $\xi$ :

$$
\frac{\mathrm{E}_{2}}{\mathrm{E}_{1}}=\frac{\mathrm{P}_{2} \mathrm{U}_{2}}{\mathrm{P}_{1} \mathrm{U}_{1}}=\xi^{2}
$$

Energija direktnog talasa delimično se vraća unazad u vodu, a delimično se predaje pregradi. Zbir energije odbijenog talasa i energije koja se predaje pregradi mora biti jednak energiji udarnog talasa:

$$
\mathrm{E}_{2}+\mathrm{E}_{3}=\mathrm{E}_{\mathbf{1}}
$$

$\mathrm{Na}$ osnovu toga, moguće je odrediti deo energije koji se predaje čvrstoj pregradi (pripremku), kao rezultat delovanja udarnog talasa na nju:

$$
\mathrm{E}_{3}=\mathrm{E}_{1}-\mathrm{E}_{2}=\left(1-\xi^{2}\right) \cdot \mathrm{E}_{1}
$$

\section{Gubici energije pri odbijanju udarnog talasa od pokretne pregrade}

Neka se pregrada kreće brzinom $\mathrm{V}$ $\mathrm{u}$ istom pravcu kao i udarni talas. Ako se sa $V_{t}, V_{2}$ i $V_{3}$ označe brzine protoka tečnosti u direktnom, odbijenom $i$ prelomljenom talasu u odnosu na pokretnu pregradu, te brzine, u odnosu na nepo- kretnu ploču i brzine same ploče, mogu se napisati na sledeći način:

$$
\begin{aligned}
& \mathrm{V}_{1}^{\prime}=\mathrm{U}_{1}-\mathrm{V} \\
& \mathrm{V}_{2}^{\prime}=\mathrm{U}_{2}+\mathrm{V} \\
& \mathrm{V}_{3}{ }_{3}=\mathrm{U}_{3}-\mathrm{V}
\end{aligned}
$$

Tada su brzine protoka direktnog, odbijenog i prelomljenog talasa jednake:

$$
\begin{aligned}
\mathrm{U}_{1} & =\frac{\mathrm{P}_{1}}{\rho_{0} \mathrm{C}_{0}} \\
\mathrm{U}_{2} & =\frac{\mathrm{P}_{2}}{\rho_{0} \mathrm{C}_{0}} \\
\mathrm{U}_{3} & =\frac{\mathrm{P}_{3}}{\rho_{0} \mathrm{C}_{0}}
\end{aligned}
$$

$\mathrm{Na}$ osnovu navedenih jednačina može se napisati izraz za brzinu prelomljenog talasa:

$$
\mathrm{U}_{3}=\frac{\mathrm{P}_{1}+\mathrm{P}_{2}}{\rho \mathrm{C}}
$$

Po analogiji sa jednačinom za brzinu udarnog talasa (U), odnosi izmedu brzina protoka direktnog, odbijenog i prelomljenog talasa za pokretnu pregradu mogu se napisati u obliku:

$$
\mathrm{V}_{1}^{\prime}-\mathrm{V}_{2}^{\prime}=\mathrm{V}_{3}^{\prime}
$$

pa, uzimajući u obzir relacije za brzine protoka tečnosti $V_{1}^{\prime}, V^{\prime}{ }_{2}$ i $V^{\prime}{ }_{3}$, možemo napisati sledeći izraz:

$$
\mathrm{U}_{1}-\mathrm{U}_{2}-2 \mathrm{~V}=\mathrm{U}_{3}-\mathrm{V}
$$

$\mathrm{Na}$ osnovu toga može se napisati izraz za pritisak u odbijenom talasu

$$
\begin{aligned}
& \mathrm{P}_{2}=\mathrm{P}_{1} \xi-\frac{1}{2} \mathrm{~V} \mathrm{P}_{0} \mathrm{C}_{0} \frac{\mathrm{U}_{1}}{\mathrm{U}_{2}} \eta \\
& \frac{\mathrm{P}_{2}}{\mathrm{P}_{1}}=\frac{\mathrm{U}_{2}}{\mathrm{U}_{1}}=\varphi-\frac{1}{2} \frac{\mathrm{V}}{\mathrm{U}_{1}} \eta=v \\
& \text { Pri odnosu } \\
& \frac{\mathrm{V}}{\mathrm{U}}=-\frac{2 \xi}{1+\xi},
\end{aligned}
$$

koeficijent $v$ jednak je nuli. 
Srednja vrednost koeficijenta $v$ grubo se može odrediti kao srednja aritmeticka vrednost:

$$
v_{\mathrm{ur}}=\frac{\xi}{2}
$$

Eksperimentalno je pokazano [9] da takva aproksimacija u dovoljnoj meri odgovara realnosti ako se istovremeno uzme $u$ obzir $i$ koeficijent $\beta$, koji karakteriše inertnost obratka. Veza između koeficijenata $v$ i $\beta$ data je eksperimentalnim izrazom:

$$
v=\frac{\xi}{2}\left(1+\mathrm{e}^{-\beta}\right)
$$

Velicina energije koju dobija pokretna pregrada, u ovom slučaju pripremak, može se izraziti na sledeći način:

$$
E_{3}=\left(1-v^{2}\right) E_{1}
$$

Koeficijent $\beta$ predstavlja odnos mase tečnosti vodenog stuba poprečnog preseka $1 \mathrm{~cm}^{2} \mathrm{i}$ mase obratka na $1 \mathrm{~cm}^{2}$,

$$
\beta=\frac{M}{m}=\frac{p_{0} C_{0} \Theta}{\rho S},
$$

gde je:

$$
\begin{aligned}
& \mathrm{P} \text { - gustina materijala pripremka, } \\
& \mathrm{S} \text { - debljina lima. }
\end{aligned}
$$

\section{Određivanje količine eksploziva}

Kao što je već napomenuto, pri proračunu količine eksploziva uvedena je pretpostavka o ponašanju pripremka u početku izvlačenja, slično slobodnoj ploči, da pod dejstvom udarnog talasa prelazi u kretanje i vrlo brzo dostiže brzinu veću od brzine protoka tečnosti. Ako se izvlače pripremci veće debljine, koji imaju mali koeficijent $\beta$, može se pretpostaviti da se pomeranje pripremka vrši brzinom koju ima protok tečnosti.
Za pripremke veće debljine, na osnovu eksperimenata [9], mogu se smatrati pripremci za koje važi relacija:

$$
\frac{\mathrm{S}}{\mathrm{D}} \cdot 100>(6-7)^{\%} \% \text {, }
$$

što odgovara koeficijentu $\beta$ približno jednakom jedinici. Pri $\beta$ vecem od jedinice, obradak se sigurno kreće brže od protoka tečnosti, što potvrđujue i teoriju Kirkvuda [11]. Ona kaže da odvajanje obratka nastaje u slučaju kad je vreme $\Theta_{d}$, potrebno za prostiranje talasa brzinom $\mathrm{C}_{0}$ od kraja ploče do centra poluprečnika $r$, tzv. vreme difrakcije:

$$
\Theta_{\mathrm{d}}=\frac{\Gamma}{\mathrm{C}_{\mathrm{o}}}
$$

veće od vremena pojave kavitacije $\left(\Theta_{\mathcal{c}}\right)$, određenog po obrascu Tejlora [11]:

$$
\Theta_{c}=\frac{\Theta}{\beta-1} \cdot \ln \beta
$$

U slučajevima kada talas difrakcije kasni i ne uspeva da popuni razređeni prostor izmedu obratka i vode, prestaje pritisak vode na pripremak koji nastavlja kretanje i deformisanje po inerciji. Otpor plastičnom deformisanju usporava kretanje obratka, te protok vode sustiže obradak $\mathfrak{j}$ daje $m u$ novo ubrzanje, što dovodi do ponovnog odvajanja od vode. Opisano ponašanje predstavlja samo pretpastavku, jer ne postoje relevantni eksperimentalni podaci o kinetici izvlačenja tankih limova.

Sigurno je da je u većini slučajeva primećeno odvajanje obratka od vode [9]. Deformacioni rad, saopšten obrat$\mathrm{ku}$ do pojave kavitacije, malo se razlikuje od kinetičke energije koju dobija obradak, jer se ta energija ne može vratiti u vodu. U tom slučaju, može se pretpostaviti da se sva energija prelomljenog talasa $\left(\mathrm{E}_{3}\right)$ pretvara u kineticku energiju pripremka, a zatim u energiju deformacije.

$\mathrm{Na}$ osnovu toga može se napisati

$$
\mathrm{E}_{3}=\mathrm{a} \text {, }
$$


gde je:

a - energija potrebna za plastičnu deformaciju jedinice površine obratka pokvašene vodom.

Na osnovu izraza (6) za veličinu energije koju dobija pokretna pregrada (pripremak), može se napisati:

$$
\mathrm{a}=\left(1-v^{2}\right) \mathrm{E}_{1}
$$

Pri eksploziji trotila veličina energije direktnog talasa, prema Koulu [11], za sferni oblik eksplozivnog punjenja, može da se odredi izrazom

$$
\mathrm{E}_{\mathrm{t}}=95 \cdot \frac{\mathrm{G}}{\mathrm{H}^{2}} \cdot 10\left[\mathrm{Ncm} / \mathrm{cm}^{2}\right]
$$

gde su:

$\mathrm{G}$ - masa eksploziva $\mathrm{u} \mathrm{kg}$,

$\mathrm{H}$ - rastojanje od centra eksploziva do pripremka.

Ako se u izraz (7) za energiju potrebnu za plastičnu deformaciju jedinice površine zameni vrednost za $\mathrm{E}_{1}$, dobiće se izraz za određivanje potrebne mase eksploziva:

$$
\mathrm{G}=-\frac{a \mathrm{H}^{2}}{95 \cdot(1-v)^{2}}
$$

gde je:

$$
v-\text { funkcija } \beta \text {. }
$$

Sa vrednostima $\beta$ oko jedinice, sto za pripremke od celika odgovara S/D . $100=(6-7 \%)$, rezultati dobijeni po jednačini za potrebnu količinu eksploziva se dovoljno dobro podudaraju sa eksperimentalnim podacima. Sa povećanjem $\beta$, ođ̉nosno smanjenjem krutosti obradka $S / D \cdot 100$, razlika između proračunske i izmerene vrednosti postaje sve veća. Tako, npr. za $\beta=5$, proračunska vrednost za masu eksploziva iznosi 4 puta više od stvarno potrebne [7], dok pri $\beta=10(\mathrm{~S} / \mathrm{D} \approx 0,125)$ ta razlika iznosi i do 10 puta.

Još nepreciznije rezultate daje jednačina Kirkvuda [11], koja određ̆uje vezu između kinetičke energije obradka i energije direktnog talasa $E_{1}$ :

$$
\mathrm{a}=4 \cdot \beta^{\frac{1+\beta}{1-\beta}} \cdot \mathrm{E}_{1}
$$

Ako se vrednost za $E_{1}$ zameni iz jednačine za energiju direktnog talasa, konačni oblik Kirkvudovog izraza glasi:

$$
\mathrm{G}=\frac{\mathrm{a} \mathrm{H}^{2}}{4 \cdot 95 \beta^{\frac{1+\beta}{1-\beta}}},
$$

koji za $\beta=5$ daje razliku u odnosu na stvarnu količinu mase eksploziva 12 puta, dok za $\beta=10$ ta razlika ide i do 34 puta u smislu povećanja potrebne kolicine eksploziva [9].

Relativno dobro poklapanje proračunske sa eksperimentalnom vrednošću đaje jednačina (9). To se objašnjava time, što jednačina (9) uzima u obzir odbijanje udarnog talasa u funkciji elastiěnosti obradka.

Velicina preraspodele energije može da se proceni na primeru kratkog cilindra, otvorenog sa obe strane, na kojima se nalaze klipovi različitih masa, $M$ i $m$. Između klipova je eksploziv koji pri eksploziji izbacuje klipove iz cilindra. Ako se zanemare sile trenja, pritisak gasovitih produkata eksplozije na zid cilindra, otpor vazduha, itd., može se smatrati da se celokupna energija eksplozije pretvara u kineticku energiju klipova:

$$
\mathrm{E}=\frac{\mathrm{MV}}{2}+\frac{\mathrm{m} \mathrm{V}^{2}}{2}=\mathrm{T}_{1}+\mathrm{T}_{2}
$$

gde su:

$\mathrm{V}_{1}$ i V - brzine pomeranja klipova, $\mathrm{T}_{1}$ i $\mathrm{T}_{2}-$ kinetičke energije,

Ako mase klipova nisu jednake, tada ni kinetičke energije neće biti jednake. Uzimajući u obzir da je pritisak produkata eksplozije jednak na oba klipa, tada se, na osnovu drugog Njutnovog zakona, može napisati:

$$
\mathrm{P}=\mathrm{M} \frac{\mathrm{dV}}{\mathrm{dt}}=\mathrm{m} \frac{\mathrm{dV}}{\mathrm{dt}}
$$


Ako se izvrši integraljenje ove jednačine, dobija se:

$$
\mathrm{M} \cdot \mathrm{V}_{1}=\mathrm{m} \cdot \mathrm{V}
$$

Ako se leva i desna strana jednačine (14) kvadriraju i podele sa 2 , dobija se izraz:

$$
\mathrm{M} \frac{\mathrm{M} \mathrm{V}_{1}^{2}}{2}=\mathrm{m} \frac{\mathrm{m} \mathrm{V}^{2}}{2},
$$

odnosno

$$
\frac{\mathrm{M}}{\mathrm{m}}=\frac{\mathrm{T}_{2}}{\mathrm{~T}_{1}},
$$

tj. veličine kineticke energije su obrnuto proporcionalne njihovim masama. $\mathrm{Na}$ osnovu toga može da se izvede zaključak da cé i preraspodela energije eksplozije, u zavisnosti od mase okolne sredine, biti po tom zakonu.

Ovaj zaključak nema strogu teorijsku osnovu, ali ga nalaže logika eksperimentalnih podataka. Oni se poklapaju sa proračunskim a slučaju da je preraspodela energije za eksploziju sfernog punjenja od brizantnog eksploziva u vodi, na rastojanju ne manjem od 0,3 i ne većem od dva prečnika okvašene površine obradka, obrnuto proporcionalna odnosu masa uslovnog paralelopipeda $\mathrm{M}=\rho_{0} \cdot \mathrm{C}_{10} \Theta$ i mase jedinice površine obradka $\mathrm{m}=\rho \cdot \mathrm{S}$

$$
\frac{\mathrm{M}}{\mathrm{m}}=\frac{\rho_{0} \mathrm{C}_{0} \Theta}{\rho \mathrm{S}}=\beta
$$

Za velicinu energije sada se uzima jednačina

$$
\mathrm{E}_{\mathrm{l}}=\beta \cdot 95 \cdot \frac{\mathrm{G}}{\mathrm{H}^{2}}
$$

Ako je eksplozija izvršena u vodi, sto znači da je $\rho_{0}=1 \mathrm{gr} / \mathrm{cm}^{3}$ i $\mathrm{C}_{0}=$ $=15 \cdot 10^{4} \mathrm{~cm} / \mathrm{s}$, onda će vremenska konstanta, prema [11], biti

$$
\Theta=10^{-4} \cdot \mathrm{Q}^{1 / 3}\left(\frac{\mathrm{H}}{\mathrm{G}^{1 / 3}}\right)^{0^{\prime 24}}[\mathrm{~s}]
$$

gde su:

$\mathrm{H}$ - rastojanje od centra eksploziva do pripremka [mm],

$\mathrm{G}$ - masa eksploziva [kg].

Sada će se, posle zamene izraza za $\beta$ i $\Theta \leftarrow$ (16), dobiti konačan izraz za određivanje količine eksploziva sfernog eksplozivnog punjenja:

$$
\mathrm{G}=\left[\frac{\mathrm{aS} \mathrm{H} \mathrm{H}^{1, \mathrm{~B}}}{1-v^{2}} \cdot \mathrm{N}\right]^{0,8}
$$

Ovaj obrazac daje koliěinu eksplozivnog punjenja u [kg], a sve dužinske mere su u $[\mathrm{cm}]$. Vrednosti koeficijenta $N$, koji zavisi od gustine materijala obradka, date su u tabeli.

Vrednost koeficijenta $N$ za neke materijale

Tabela

\begin{tabular}{|l|c|c|c|c|}
\hline $\begin{array}{c}\text { Vrsta } \\
\text { materijala }\end{array}$ & $\rho$ & $\varphi$ & $1-v^{2}$ & $\mathrm{~N}$ \\
\hline $\begin{array}{l}\text { Legure } \\
\text { alumiri- } \\
\text { juma }\end{array}$ & 2,8 & 0,840 & 0,824 & $0,49410^{-6}$ \\
\hline Celik & 7,8 & 0,936 & 0,781 & $1,37610^{-6}$ \\
\hline
\end{tabular}

Ako je sferno eksplozivno punjenje na rastojanju manjem od 0,3 prečnika okvašene površine obradka, tada, usled lokalne deformacije, obradak nece dobiti sferni nego konusni oblik. U tom slučaju, jednačina (18) ne važi, a izvlačenje na bliskom rastojanju treba izvoditi ne sfernim već ravnim (pločastim) eksplozivnim punjenjem.

Na osnovu izvoda u literaturi i raznih eksperimentalnih istraživanja došlo se do izraza na osnovu kojeg se određuje količina eksploziva po jedinici okvašene površine pripremka (odnosi se na eksploziv VITEZIT) [5, 7]:

$$
\begin{aligned}
& \mathrm{q}=0,0113 \cdot \mathrm{S}^{0,972} \cdot \mathrm{K}^{4,134} \cdot \mathrm{H}_{0}{ }^{0,582} \\
& {[\mathrm{~kg}],}
\end{aligned}
$$


gde su:

$\mathrm{S}$ [mm] - debljina lima koji se izvlači;

$\mathrm{K}$ - odnos izvlačenja,

$\mathrm{H}_{\circ}[\mathrm{mm}]$ - rastojanje eksplozivnog punjenja od površine pripremka (preporučljiva vrednost $\mathrm{H}_{0}=(0,3-0,4) \mathrm{D}$, gde je D - prečnik okvašene površine pripremka).

Kolicina potrebnog eksploziva može da se izrazi i preko zatezne ěvrstoće $\mathrm{R}_{\mathrm{m}}$. Tako definisana zavisnost, za čelik i bakar, ima oblik:

$$
\begin{aligned}
& \mathrm{q}=2,69 \cdot 10^{-5} \cdot \mathrm{R}_{\mathrm{rn}} \mathrm{S}^{0,972} \cdot \mathrm{K}^{4,134} . \\
& \cdot \mathrm{H}^{0,562}[\mathrm{~kg}]
\end{aligned}
$$

Pri određivanju količine eksploziva modelovanjem polazi se od toga da se, nakon određivanja količine eksploziva potrebnog za oblikovanje, pomoću zakona sličnosti odredi potrebna kolicina eksploziva za oblikovanje prototi$\mathrm{pa}$, odnosno zahtevanog elementa-dela.

Za dobijanje tačnog modela potrebno je eliminisati neka ograničenja i postići potpunu geometrijsku sličnost modela i prototipa; veličine krutosti opruga i vijaka za pritezanje držača lima i sile držača lima prototipa i modela moraju biti u određenom odnosu; pritisci vazduha u šupljini matrice (alata) i koeficijenti trenja između pripremka, držača lima i alata za prototip i model moraju biti isti; plastična naprezanja u materijalu prototipa i modela moraju biti jednaki, itd.

Praktična ograničnja utiču da se ne može uvek naći potpuno adekvatan model (npr. za isti materijal pripremka mogu postojati razlike u osobinama plastičnosti koje odgovaraju razlici između ploče metala veće i manje debljine]. Ako se uzme u obzir činjenica da se može modelovati i sa različitim materijalima, onda se može govoriti samo o aproksimativnom modelu.

Aproksimativni model zakona proporcionalnosti za koljčinu eksplozivnog punjenja dat je izrazom [8]:

$$
\mathrm{G}_{\mathrm{p}}=\left[\mathrm{a}_{\mathrm{II}} \cdot \mathrm{a}_{\mathrm{s}} \cdot \mathrm{a}^{\mathrm{g}}\right]^{\mathrm{B} \cdot{ }^{\mathrm{B}+1} \cdot \mathrm{G}_{\mathrm{inn}}}
$$

gde su:

$\mathrm{G}_{\mathrm{p}}$ - masa eksplozivnog punjenja za model,

$\mathrm{G}_{\mathrm{rt}}$ - masa eksplozivnog punjenja za prototip,

$a_{m}$ - korekcioni faktor materijala,

$a_{s}$ - faktor debljine lima,

$a_{k}$ - geometrijski faktor,

B - koeficijent koji zavisi od vrste eksplozivnog punjenja.

Pri tome je korekcioni faktor materijala $\left(a_{31}\right)$ dat izrazom [8]:

$$
\begin{gathered}
a_{n n}=\frac{K_{p}}{K_{m}}\left[\frac{\left(n_{m}+1\right) \cdot\left(n_{m n}+2\right) \cdot\left(n_{m}+3\right)}{\left(n_{n}+1\right) \cdot\left(n_{p}+2\right) \cdot\left(n_{n}+3\right)}\right] . \\
{\left[\frac{8}{D^{2}}\right]\left(h_{p}^{2}-n_{n n}\right)}
\end{gathered}
$$

gde su:

$\mathrm{K}_{\mathrm{p}}, \mathrm{K}_{\mathrm{m}}, \mathrm{n}_{\mathrm{p}}, \mathrm{n}_{\mathrm{m}}$ - koeficijenti koji zavise od vrste materijala,

$h_{0}$

D

- maksimalna dubina izvlačenja metala,

- prečnik otvora alata.

Primenom teorije modelovanja procesa hidroizvlačenja eksplozivom može da se odredi potrebna količina eksploziva za izvlačenje bilo kojeg dela oblika danca, ako je poznata kolicina eksploziva za izvlačenje nekog modela. Izraz za to ima oblik [7]:

$$
\mathrm{G}_{\mathrm{p}}=\mathrm{G}_{\mathrm{m}} \cdot \mathrm{N}_{\mathrm{r}}^{2} \cdot \mathrm{N}_{\mathrm{s}}[\mathrm{kg}\rfloor,
$$

gde su:

$\mathrm{G}_{\mathrm{p}}=\mathrm{q} \cdot \mathrm{A} \quad$ - količina eksploziva $\mathrm{za}$ odgovarajuće dance u [kg],

$\mathrm{A}[\mathrm{mm}]$ - površina okvašene površine pripremka,

$\mathrm{G}_{\mathrm{m}} \quad-$ kolicina eksploziva na model,

$\mathrm{N}_{\mathrm{r}}=\mathrm{D}_{\mathrm{p}} / \mathrm{D}_{\mathrm{m}}-$ koeficijent modelovanja za prečnik,

$\mathrm{N}_{\mathrm{g}}=\mathrm{S}_{\mathrm{p}} / \mathrm{S}_{\mathrm{m}}$ - koeficijent modelovanja za debljinu lima. 


\section{Zaključak}

Pri detonaciji čvrsti eksploziv potpuno ili pretežno prelazi u gasovite produkte koji su jako zagrejani i pod visokim pritiskom. Pošto se nalaze pod pritiskom, koji znatno premašuje pritisak okoline, gasovi su u stanju da na račun svoje unutrašnje toplote energije izvrše neki rad.

Proces detonacije eksploziva, koji nije zatvoren, potpuno je ireverzibilan, tj. ni $u$ jednom trenutku ne postoji ravnoteža između pritiska i spoljnih sila. Najveći deo energije preobratiće se u udarni talas u vazduhu, gde se transformacija energije vrši po tipično nepovratnom procesu $u$ toplotu, koja ce se utrošiti na zagrevanje okoline. Termodinamixki posmatrano, ovaj proces bio bi okarakterisan degradacijom toplotne energije. Toplotna energija detonacionih gasova, na srazmerno visokom temperaturnom nivou, degradira se $\mathrm{u}$ toplotu na temperaturnom nivou okoline.

Ako eksplozive apliciramo u slobodnom prostoru, prislonjene ili sasvim blizu objektu na koji treba delovati detonacijom, oni će izazvati određeno destruktivno dejstvo. Sposobnost razornih eksploziva da izvrše rad i u slobodnom prostoru - brizantnost, zavisi isključivo od gasnog impulsa, tj. od pritiska gasova, a zatim i od vremena za koje se pritisak održava iznad neke kritične vrednosti.
Najěešći oblik punjenja pri oblikovanju lima eksplozijom je sfera. Kod eksplozivnih punjenja u obliku sfere stvara se centralnosimetrični udarni front.

Veliki uticaj na proces oblikovanja ima visina postavljanja eksploziva iznad pripremka. Kod distancionih procesa, kod kojih se eksplozivno punjenje nalazi na određenom rastojanju od pripremka, udarni talas može padati prema pripremku normalno ili pod uglom. Povećanje visine položaja eksploziva dovodi do povećanja količine eksploziva potrebnog za deformaciju lima, povećava troškove izrade ostale opreme (bazen sa vodom) i vreme ponovnog punjenja bazena.

Količina eksploziva potrebnog za deformisanje lima pri oblikovanju eksplozijom jedan je od najvažnijih parametara procesa. Ta količina, koja ce dovesti do obIikovanja lima, treba da bude minimaIna, a da pri tome ne preopterećuje delove alata i bazena. $\mathrm{Za}$ tačno određivanje potrebne količine eksploziva ne postoji egzaktna teorija zasnovana na fizici eksplozije, s jedne strane, i na stavovima iz teorije elastičnosti, s druge strane.

Stoga je zadatak da se pronađe optimalan izraz, koji će zadovoljiti i eksperimentalne podatke $i$ biti $u$ saglasnosti sa odgovarajucim oblikom obrat$\mathrm{ka}$, složeniji i iziskuje neprekidno istraživanje na polju osobine materijala uslovi i vrste opterecenja - vrsta i količina eksploziva.

\section{Leterattita:}

[1] Krupin A, V. i dr.: yDeformacija metallov vzrivome, Mašinostroenie, Moskva, 1975.

[2] Iunov, V. I., Ogibalov P. M.: \#Naprjaženija v telah pri impul'snom nagruženif , Moskva. 1975.

[3] bel]ajev V. N.: \$V1sokoskorostnaja deformacija metallov, Nauka i tehnika, 1976.

14] Deribas A. A.: \$Fizika uporočnenia i svarkl vzrivom*, Novosibjrsk, Nauka, 1980.

[5] Dimitrov B.: sDoktorska disertacija*, Mas̆ingłki fakultet Niş, 1987.

r6) Radić V.: *Obrada metala eksplozjjome, VTG 1: 1990.

[7] Dimitrov B., Stolljkovié V.: Analiticko-eksperimentalni način određivanja količlne eksplos'va pri hidroeksplozivnom izvlacenju delova od limax, AMSTL Opatija, 1987.

[i] Hegazy A. A.: $\rightarrow$ A Theory for Aproximate Model for Underwater Explostve Forminga, 10th HERF 89, Ljubljana.

[9] Pihtovnikov R. V., Zavjalova V. N.: >stampovka listovoga metalla vzrivomx, Mašinostroenie; Moskva. 1864.

[10] Davidenkọ N. N.: Dinamiceskie ispitanj]a metallov๔, Moskva, 1966.

[11] Antonenkov N. D, Anjčin M. A.: stampovka podvodnim vzrivoma, Moskva, 1967.

[12] Hegazy A. A., i dr.: $\rightarrow$ Experimental Verification of the Theory of Aproximate Model for Underwater Explostve Sheet Metal Formingc, 10th HERF 89, Ljubljana.

[13] Duhandž́c S.: sUporedna analiza eksperimentalnog određivanja kolicine eksplozlva 1 modeliranja pri hidroeksplozivnom oblikovenju metalax, 18. Simpozisum JKEM, Kupari, 1900. 